\title{
A Study of the Adequacy of Training in Mechanical Engineering in Relation to Business Profiles
}

\author{
Zineb Ait haddouchane ${ }^{1}$, Souad Ajana ${ }^{2}$, Imane Zergout ${ }^{1}$, Kenza Faraj $^{3}$ \& Soumia Bakkali $^{4}$ \\ 1 PhD Student, Department of Mechanical Engineering, Higher National School of Electricity and Mechanics, \\ Hassan II University of Casablanca, Morocco \\ ${ }^{2} \mathrm{PhD}$, Department of Mechanical Engineering, Higher National School of Electricity and Mechanics, Hassan II \\ University of Casablanca, Morocco \\ ${ }^{3} \mathrm{PhD}$, Department of Mathematics and Computer Engineering, Higher National School of Electricity and Mechanics, \\ Hassan II University of Casablanca, Morocco \\ ${ }^{4}$ PhD, Department of Electrical Engineering, Higher National School of Electricity and Mechanics, Hassan II \\ University of Casablanca, Morocco
}

Correspondence: Zineb Ait haddouchane, PhD Student, Department of Mechanical Engineering, Higher National School of Electricity and Mechanics, Hassan II University of Casablanca, Morocco

Received: December 4, 2018

Accepted: December 18, $2018 \quad$ Online Published: December 20, 2018

doi:10.5430/ijhe.v7n6p173

URL: https://doi.org/10.5430/ijhe.v7n6p173

\begin{abstract}
This project is a contribution to the continuous improvement of the education of engineers, which involves all the stakeholders in the field. It presents the primary results of a quantitative study of mechanical engineering training in the Higher National School of Electricity and Mechanics (École Nationale Supérieure d'Électricité et Mécanique ENSEM), in collaboration with numerous Moroccan industrialists. The first phase of the research consisted in the issue as well as the research methodology adopted. In the second phase, a survey instrument was developed based on the competency framework as a research model, and then the hypotheses to be tested were outlined. Then, a questionnaire was designed and pre-tested for the purposes of this examination, which was subsequently completed by industry leaders from different sectors. The results obtained show the strengths and weaknesses in ENSEM's training in mechanical engineering and reveal the correlations between the various engineering competencies. The paper finally ends with a listing of recommendations to address the diverse issues identified, in addition to a statement of the further prospects for this research.
\end{abstract}

Keywords: adequacy, job-training, mechanical engineering, skills, education continuous improvement

\section{Introduction}

Globalization has a great impact on the labor market since it creates new needs and engenders strong competition. Therefore, specialized competencies are required in a variety of highly professional occupations (Terfous, 2006).

During the course of initial training, the level of skills acquisition remains crucial in the recruitment process, since the level of acquisition distinguishes between highly-qualified and poorly-qualified engineers. Nowadays, there is ever increasing competition among Higher Schools in regard to quality training opportunities. Therefore, continuous improvement of engineer training is necessary in terms of the knowledge, expertise and social skills (savoir, savoir-faire, savoir-être) that can be valuable in diverse contexts.

As one of the countries experiencing unprecedented economic growth through an Industrial Acceleration Plan, Morocco increasingly stresses the importance of quality training. In this plan, it is suggested that the competencies required in the labor market must be expressed by the leading industrialists, and that the required profiles ought to be developed for each ecosystem.

The issue of the training-employment match needs to be defined for three reasons: firstly, it interests fresh graduates who have diverse training profiles, secondly, it corroborates the thought that professional experience develops the skills of the individual, and finally, it involves the idea that the competence acquired through initial training can also be assimilated by the expertise associated with the elements of training (Vincens, 2005). 
In a previous review of literature on the adequate fit between training and employment (Ait haddouchane, Bakkali, Ajana, \& Gassemi, 2017), differing trends and approaches were identified. In fact, this problematic can be examined from three angles: the alternation and evolution of internships during the training, the validation of professional experience and, finally, the entrepreneurial reference of education and professional activity (Champy-Remoussenard, 2015). The subject matter can also be addressed by comparing the training systems in different countries and then conducting a study to determine the system that satisfies the requirements of business profiles the most, in order to try to adopt it (Charles, 2014). The training-employment match is one of the key features of the competency-based approach. Therefore, it seemed necessary to use this approach to improve training programs in order to produce graduates who satisfy the requirements of the job market (Deschryver, Charlier, \& Fürbringer, 2011). Another movement links the issue of the training-employment fit to the uncertain quality of diplomas and the length of time necessary to ascertain the skills acquisition level of a laureate. This led to suggesting the use of competitive examinations for recruitment, the extension of probationary periods, etc. (Felouzis, 2008).

In this work, the competency-based approach was adopted in order to tackle this problem. Such an approach emphasizes not only the cognitive aspects, but also the current societal challenges, while guaranteeing efficiency and relevance at the level of curricula. It ensures equity and makes all stakeholders aware of their responsibility, especially the students (Roegiers, 2016). The competency-based approach also guarantees a variegated usage in the field of training design, by expressing the call for knowledge, the understanding of competencies, the demand for more appropriate evaluation methods and a re-acquisition of the training course by the student (Chauvigné, \& Coulet, 2010).

Although frequently used, the term "competency" has been defined by several authors (Aubret, 1993; LeBoterf, 1994; Zarifian, 1999; Tardif, 2006) and is understood in different ways. This was the subject of many criticisms and debates. Nevertheless, the components of a competency can be grouped consensually into seven categories (Mérenne-Schoumaker, 2006):

- a behavioral awareness

- a certain anchoring in real-world situations

- a close link with the different aspects of knowledge

- a development of disciplinary and transversal skills

- a development of individual and collective competencies

- a capacity for reflexivity

- the acquisition of a certain amount of autonomy.

The interface allowing for the transition from the world of work to the world of training is the competency framework that forms the basis of the pedagogical part of the work. The framework links the requirements of the profession to the individuals in accordance with human resources management, training and evaluation (Roegiers, 2010).

Raisky and Cros (2010) defined the roles of the competency framework according to the professional and academic aspects. Flowchart 1 presents the different roles mentioned. 


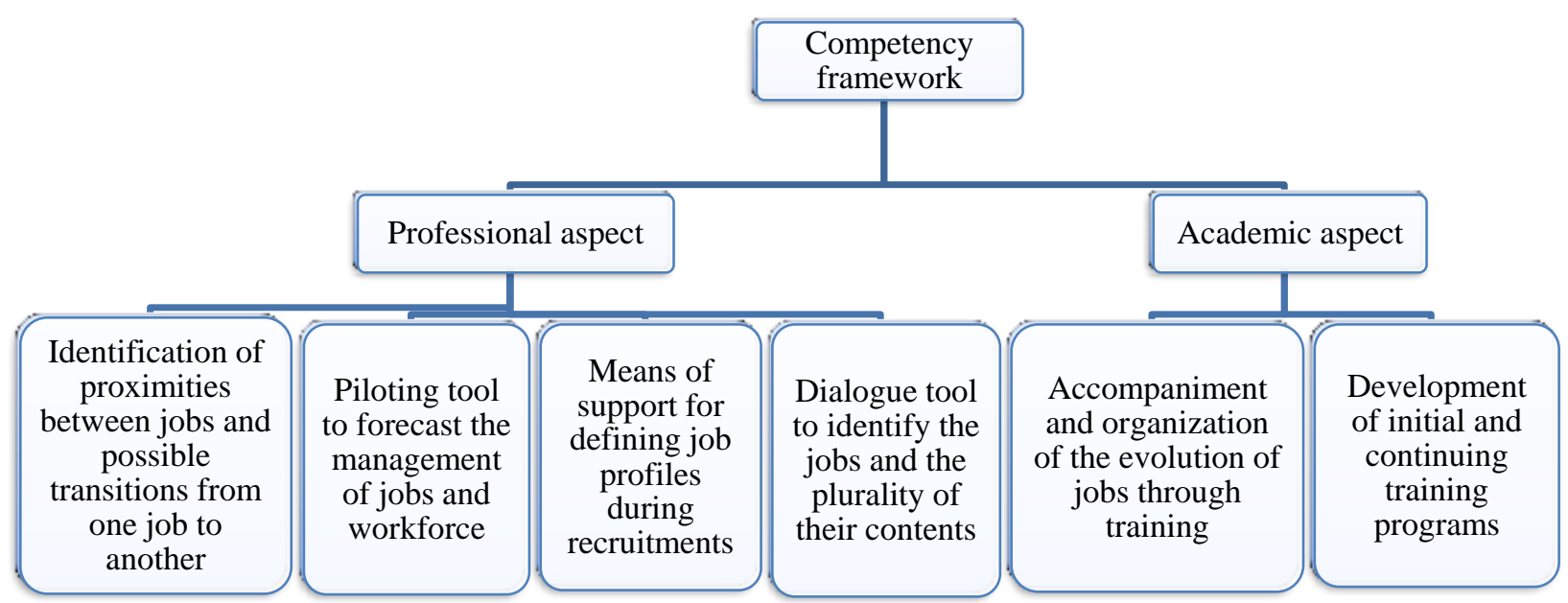

Flowchart 1. Role of the competency framework at the level of the professional world and training (Cros, \& Raisky,

2010).

In 2003, the Moroccan government decided to reform its higher education system through the Bologna Process, which is a vehicle for inter-university cooperation, cultural exchanges and the affirmation of a European model. The objective is to create a common higher education space and to unify the procedures that govern it (the 'LMD' or 'graduate, post-graduate and doctorate' system) (Ghouati, 2010; Gardelle, Cardona Gil, Benguerna, Bolat, \& Naran, 2017).

In Morocco, Engineering Schools initiated the implementation of the specialization system in 2007. They have accreditation descriptions that include the training programs taught and which are reviewed every four years, but they lack competency frameworks. Indeed, competency frameworks are necessary because they serve both as a reference to be followed for the development of training documents and as a final objective to be achieved since the ultimate goal of the training is to prepare the learner to be able to carry out the activities of the trade.

Training in engineering sciences in Morocco lasts three years preceded by two years of preparatory classes. Students sit competitive entrance examinations which allows them to be assigned to different engineering schools according to their ranking.

It should also be noted that Moroccan engineers are trained in state or private schools. The state sector includes 28 schools and 5 Faculties of Science and Technology offering training for engineers, among which we can mention the Mohammadia School of Engineers (Ecole Mohammadia d'Ingénieurs - EMI), the Hassania School of Public Works (Ecole Hassania des Travaux Publics - EHTP) and the Higher National School of Electricity and Mechanics (Ecole Nationale Supérieure d'Electricité et de Mécanique - ENSEM) (http://www.9rayti.com/ecoles/ecole-dingenieur).

In 2014, the National Industrial Acceleration Plan 2014-2020 was born to give Morocco a new boost by strengthening its economic resilience, consolidating its place among the emerging nations of America, Europe, the Middle East and Africa and heading towards a more certain economic path. Training is vital to the success of this project when it matches the profiles required by the labor market. It is a means to attract national and international investors and to participate in the progress and the competitiveness of companies (MIICEN, 2014). In fact, engineers are among the important human resources required to meet the needs of different economic fields.

This work highlights the training of engineers at ENSEM in order to conduct a qualitative adequacy study. This school has academic programs under four engineering disciplines: mechanical engineering, electrical engineering, computer engineering and industrial engineering.

The objective of this work is to accentuate the qualitative fit between the training and employment of engineers, the latter being one of the key human resources that have to identify and meet the needs of different economic sectors. This undertaking starts first with a presentation of the problem and the research methodology adopted to conduct this investigation; the latter is based on the competency framework of the Swiss Federal Institute of Technology of Lausanne (École Polytechnique Fédérale de Lausanne - EPFL) as a research model. The paper proceeds to detail the entire process of the research undertaken, namely, listing the hypotheses, describing the sample (the participants in 
the questionnaire), analyzing the statistical results and finally suggesting some preliminary recommendations that are to be discussed in a future examination.

\section{Issues and Research Methodology}

Engineers are part of the vital human resources that contribute to the evolution of a company, given the wide range and variety of responsibilities assigned to them. According to Gardelle, Cardona Gil, Benguerna, Bolat, \& Naran, (2017):

Engineering training is considered as highly strategic for Morocco, which relies on industrial development and the knowledge economy. There are many initiatives, from teachers, from heads of trainings and from the upper echelons to think and to act for the qualitative and quantitative development of engineering training, searching for inspiration from around the world. (Gardelle, Cardona Gil, Benguerna, Bolat, \& Naran, 2017, p. 208)

This research paper starts with the analysis of the status quo of the skills acquisition level of fresh graduates. The purpose is to determine the competencies that Moroccan engineers should have so that they better meet the needs of the Moroccan labor market, and consequently the quality of engineer training can be enhanced (MIICEN, 2014). The match between training and employment is a subject that can be approached from different perspectives and on diverse levels within the various training programs. The questions that arise from the training or the job market environments generate important issues which may be technical and managerial. The endeavor at this stage is to identify the problematic question to be scrutinized: How could we improve the quality of the training of ENSEM engineers so that they embody the skills required by the labor market? The training-employment fit is a problematic that cannot be tackled in a direct way since it is of a causal and explanatory nature. There is a need to answer the following two general research questions:

- General Research Question 1: Does the training of an ENSEM engineer ${ }^{1}$ qualitatively meet labor market requirements?

- General Research Question 2: What are the competencies that characterize the ENSEM engineer? And what are the competencies to be developed?

The objectives of this study are to show the strengths and weaknesses in ENSEM's training in mechanical engineering in comparison with labor market requirements and reveal the correlations between the various engineering competencies.

The choice of mechanical engineering is due to the fact that it represents a strategic field for ENSEM, given the high number of its laureates who meet the needs of Moroccan industry and its economy. Indeed, the number of graduates in this discipline increased from 75 in 2013 to 89 in 2017, signaling an increase in the percentage of all graduates as well: from $37 \%$ to $41 \%$. The aim is also to improve the employability rate of these graduates by improving their training for a better training-employment fit.

This investigation is therefore led, initially, to immerse all stakeholders in the context of the training of Moroccan engineers as well as in their work environments. Measuring the gap between the training programs and business profiles in terms of competencies requires a field study to be conducted in order to better explain the topic of the training-job match. The aforementioned field study is relevant because it involves several stakeholders: industrialists and engineers who have recently joined the professional world. In a second step, we will suggest action plans on the training program level in Engineering Sciences. Based on this approach, the constructivist paradigm was chosen to provide answers to our research questions. Indeed, in constructivism, the object of research can be compared to a project of construction and comprehension of a reality that is grasped and explained; such a project is constantly dependent on stakeholders, researchers and their action plans (Grenier, \& Pauget, 2007).

The research methodology adopted in this study is one which has proven adequate to attain objective knowledge through the scientific method. The methodology opted for is appropriate to the object of study and the research questions, and it serves to better grasp the phenomenon at hand. In the current case, it is an explanatory piece of research, which has led to the adoption of a quantitative methodology. John W. Creswell (2013) explains in his book, Research Design: Qualitative, Quantitative, and Mixed Methods Approaches, that such methodology is employed when probing a problematic with causal and explanatory aspects, and when measurable variables formulated in a hypothesis exist (Creswell, 2013).

The primary task at this level was to choose the appropriate research model. Then, the research hypotheses that were to be examined in this study were put forward. Next, the diverse parts of the questionnaire, which had been tested on 
the industrialists, were carefully designed. After selecting the group of participants (i.e. the sample), the data were collected and analyzed in order to be able to answer the aforementioned research questions. The steps of the quantitative methodology adopted in this study are summarized in Flowchart 2.

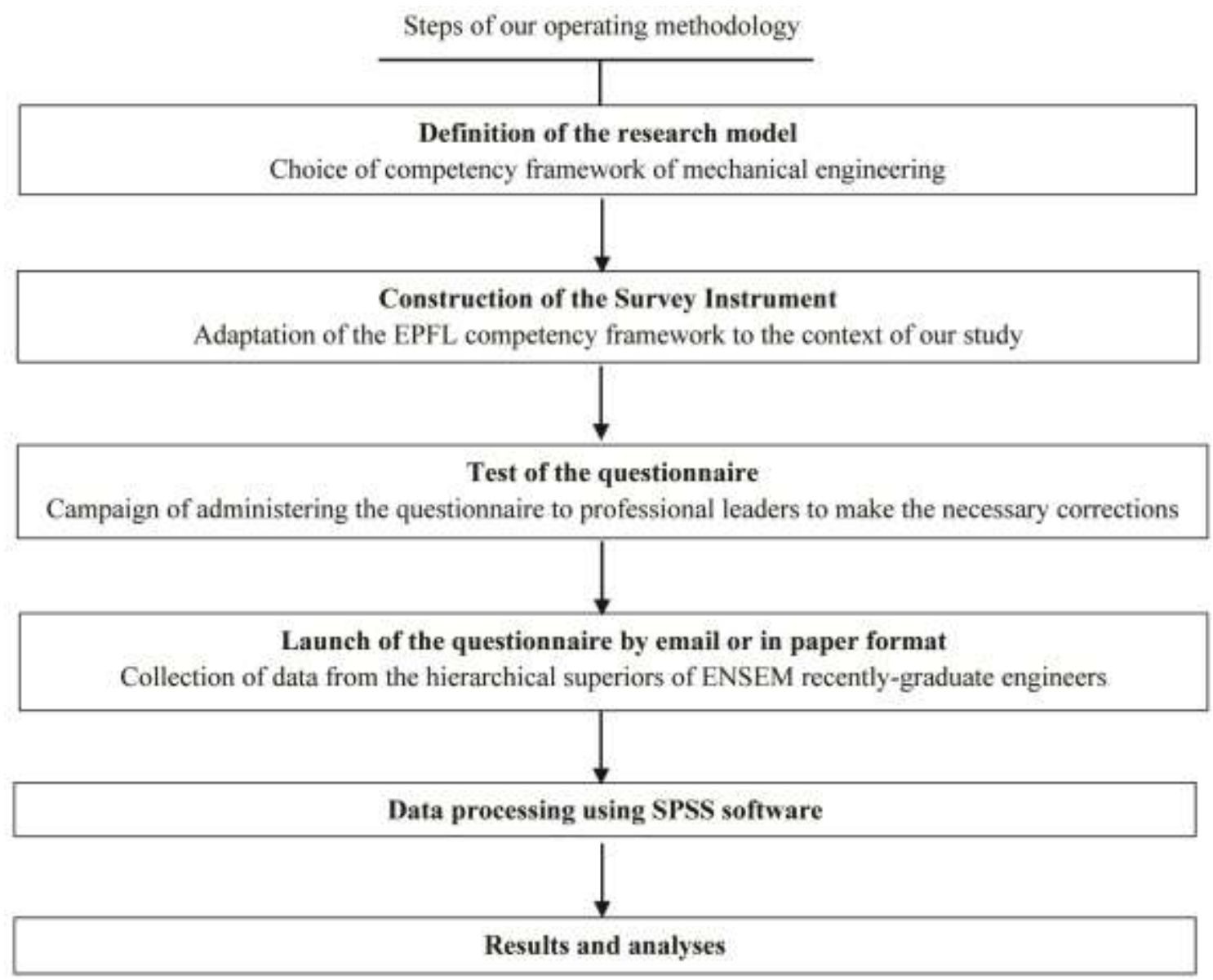

Flowchart 2. Steps of our operating methodology

\section{Construction of the Survey Instrument}

\subsection{Research Model}

The competency framework of mechanical engineering of the Swiss Federal Institute of Technology Lausanne (École Polytechnique Fédérale de Lausanne - EPFL) is the basis of this research. This reference frame was selected after a critical study of Francophone mechanical engineering competency frameworks (Ait haddouchane, Faraj, Bakkali, \& Ajana, 2016). This choice is due to the following facts:

- the similarity between the Francophone training system and the Moroccan training system;

- the necessity to preserve the homogeneity of the sample of competency frameworks.

The competency framework of the EFPL is characterized by its simplicity and comprehensibility. Besides, it has a generic and therefore transposable aspect, in addition to specific characteristics treated at the level of learning outcomes. Moreover, the study plan was elaborated based on the simple axes close to Bloom's taxonomy. All components of the competency framework are detailed in the final document as well as the links between them. The framework is thus characterized by:

- The hierarchy of macro-competencies and their components: it contains a diversified description of evaluable, interdependent skills and a limited number of components ranging from three to five.

- Formatting: it brings together the elements that constitute it in a well-ordered summary table.

- The definition of the methodology of elaboration: the design process is well detailed and based on the competency-based approach. In addition, the various stakeholders involved in its implementation are cited, 
namely teachers of the mechanical engineering section, engineers, guidance counselors and managers who agreed to respond to the Delphi study.

- Identification of training situations: for each component, examples of training situations to develop competencies are proposed. Among other things, seminars on analytical technologies, practical projects and training on specific tools are mentioned.

- Identification of professional situations: it contains different professional situations that can be confronted by a mechanical engineer and the requisite competencies to be demonstrated for each situation.

- Identification of key concepts: we find the knowledge, the expertise and the social skills that should be required from students according to well-defined standards of mastery.

The EPFL competency framework for mechanical engineering and the study plan were used as a reference in several works mentioned in Table1:

Table1. Works that used the EPFL competency framework and study plan as reference

\begin{tabular}{|c|c|c|c|}
\hline Authors & Article Title & $\begin{array}{l}\text { Methodological framework of the } \\
\text { study }\end{array}$ & Main results \\
\hline $\begin{array}{l}\text { (Filippi, } \\
\text { Cantaroglou, } \\
\text { Gerbé, \& } \\
\text { Raynauld, 2012) }\end{array}$ & $\begin{array}{l}\text { Du portefeuille de } \\
\text { formation au portfolio } \\
\text { de compétences : } \\
\text { valoriser } \\
\text { communautés les } \\
\text { professionnelles pour } \\
\text { favoriser l'accès à } \\
\text { l'emploi }\end{array}$ & $\begin{array}{l}\text { Structuring of tools through the } \\
\text { creation of an After Training Service } \\
\text { for Students to: } \\
\text { * Improve workplace integration } \\
\text { * Develop offers for continuing } \\
\text { training for students in case of } \\
\text { resumption of studies. }\end{array}$ & $\begin{array}{l}\text { Implementation of a } \\
\text { portfolio valuing the } \\
\text { competencies and the } \\
\text { matching of training } \\
\text { courses with the } \\
\text { requirements of the job } \\
\text { market so as to improve } \\
\text { the curricular section of } \\
\text { the professional-social } \\
\text { network. }\end{array}$ \\
\hline $\begin{array}{l}\text { (Basque, } \& \\
\text { Rogozan, 2013) }\end{array}$ & $\begin{array}{l}\text { Vers une méthode } \\
\text { d'ingénierie } r \text { de } \\
\text { l'approche-programme } \\
\text { en enseignement } \\
\text { supérieur }\end{array}$ & $\begin{array}{l}\text { * Literature review of the program } \\
\text { approach: identification of the } \\
\text { conceptual framework and the } \\
\text { conclusions deduced from feedback } \\
* \text { Collection of data through } \\
\text { interviews with contributors who } \\
\text { applied or completed a theoretical } \\
\text { reflection on the program-approach } \\
\text { model to integrate them into the } \\
\text { engineering method. } \\
\text { * Elaboration of the method using } \\
\text { the graphical representation of } \\
\text { knowledge aspects, known as } \\
\text { "modeling by typified objects". }\end{array}$ & $\begin{array}{l}\text { Construction of the first } \\
\text { level of the model for } \\
\text { engineering the program } \\
\text { approach with different } \\
\text { processes ... }\end{array}$ \\
\hline $\begin{array}{l}\text { (Postiaux, } \\
\text { Robert, 2013) }\end{array}$ & $\begin{array}{l}\text { Référentiel de } \\
\text { compétences et } \\
\text { learning outcomes à } \\
\text { l'Ecole Polytechnique } \\
\text { de Bruxelles: Un } \\
\text { modèle pour tenter la } \\
\text { réconciliation }\end{array}$ & $\begin{array}{l}\text { *Reference framework: } \\
\text { Competency-based approach } \\
\text { *Positioning of the concept of } \\
\text { "learning outcomes" within a model } \\
\text { based on the notion of competency. }\end{array}$ & $\begin{array}{l}\text { Elaboration of an } \\
\text { integrated framework of } \\
\text { competencies and } \\
\text { learning outcomes. }\end{array}$ \\
\hline
\end{tabular}

\subsection{Research Hypotheses}

The five competencies in the chosen research model are diverse, measurable, and interdependent, and they have a limited number of components ranging from three to five as explained in Section 4.2 of this article. The aim is to obtain a detailed valuation of competency components on two levels, the level of importance and the level of acquisition, by setting the following value rating scale: 


\begin{tabular}{ll}
\hline Value of the Level of Importance & Value of the Level of Acquisition \\
\hline $1:$ unimportant & $1:$ not acquired \\
$2:$ slightly important & $2:$ moderately acquired \\
$3:$ important & $3:$ properly acquired \\
$4:$ very important & \\
\hline
\end{tabular}

The research hypotheses we want to verify in this study are presented in Table 2:

Table 2. Research hypotheses

\begin{tabular}{|c|c|c|}
\hline Skills & For the importance level & For the acquisition level \\
\hline 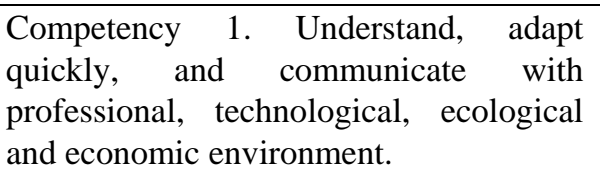 & $\begin{array}{l}\text { The level of importance of } \\
\text { Competency } 1 \text { is "very } \\
\text { important". }\end{array}$ & $\begin{array}{l}\text { The level of acquisition of } \\
\text { Competency } 1 \text { is "properly } \\
\text { acquired". }\end{array}$ \\
\hline $\begin{array}{l}\text { Competency 2. Starting from a complex } \\
\text { reality, identify, model and analyze } \\
\text { problems using a scientific, holistic and } \\
\text { multidisciplinary approach. }\end{array}$ & $\begin{array}{l}\text { The level of importance of } \\
\text { Competency } 2 \text { is "very } \\
\text { important". }\end{array}$ & $\begin{array}{l}\text { The level of acquisition of } \\
\text { Competency } 2 \text { is "properly } \\
\text { acquired". }\end{array}$ \\
\hline $\begin{array}{l}\text { Competency 3. Design and implement } \\
\text { innovative, effective and sustainable } \\
\text { solutions from a business and/or research } \\
\text { perspective. }\end{array}$ & $\begin{array}{l}\text { The level of importance of } \\
\text { Competency } 3 \text { is "very } \\
\text { important". }\end{array}$ & $\begin{array}{l}\text { The level of acquisition of } \\
\text { Competency } 3 \text { is "properly } \\
\text { acquired". }\end{array}$ \\
\hline $\begin{array}{l}\text { Competency } 4 . \text { Manage activities, } \\
\text { projects and people. }\end{array}$ & $\begin{array}{l}\text { The level of importance of } \\
\text { Competency } 4 \text { is "very } \\
\text { important". }\end{array}$ & $\begin{array}{l}\text { The level of acquisition of } \\
\text { Competency } 4 \text { is "properly } \\
\text { acquired". }\end{array}$ \\
\hline $\begin{array}{l}\text { Competency } 5 . \text { Develop a responsible } \\
\text { professional profile and act accordingly. }\end{array}$ & $\begin{array}{l}\text { The level of importance of } \\
\text { Competency } 5 \text { is "very } \\
\text { important". }\end{array}$ & $\begin{array}{l}\text { The level of acquisition of } \\
\text { Competency } 5 \text { is "properly } \\
\text { acquired". }\end{array}$ \\
\hline
\end{tabular}

\subsection{Design of the Questionnaire}

The questionnaire was constructed using the EPFL's mechanical engineering skills framework. This instrument included three types of information: information about the respondent, the engineer and an assessment.

The first part consisted of closed-ended, single-choice questions. These questions concerned, on the one hand, information such as the respondent's function and seniority within the company, his level of training, the branch and sector of the company, etc. and, on the other hand, information corresponding to the age, sex and sector of the engineer.

The second part consisted of five competencies divided into components. In constructing this section, we chose the Likert scale: we asked respondents to mark the assessment corresponding to their judgment. In our case, for each component, two scales were defined to measure its degree of importance as well as its degree of acquisition by the engineer. For the degree of importance, the Likert scale was used, with 4 modalities: "very important, important, slightly important, unimportant", and 3 modalities for the level of acquisition: "properly acquired, moderately acquired, not acquired". The exclusion of the neutral modality in the middle of the scale was intended to spare the respondent the effort of choosing the simplest answer that may have skewed the results.

When designing the questionnaire, various precautions were taken into consideration:

- The first page of the questionnaire included an introduction to explain the context of the questionnaire and to clarify its importance for the respondent's interest in the survey. It also included a detailed definition of the two proposed Likert scales, namely the level of importance and the level of skill acquisition.

- It was noted that the answers to the questionnaire had to be in a professional context and therefore it had to be completed in an objective manner.

- The questionnaire contained a number of questions. Therefore, to avoid discouragement among respondents, it was divided into five macro-skills that included the different components classified in a table. 


\subsection{Pre-Test of the Questionnaire}

In order to test the feasibility of the survey and the relevance of the questionnaire, the latter was subject to a pre-testing process in collaboration with ten industrials occupying different positions: Head of Assessment and Selection Service, Industrialization Managers, Human Resources Managers, Director of the Consortium of Moroccan Aeronautical and Spatial Industries, Automation Manager, Quality Managers and Maintenance Manager. This pre-test made it possible to bring some changes on a few parts of the questionnaire, such as the redefinition of the Likert scale of the acquisition level, the removal of some terms -related to the engineering of training- sometimes incomprehensible to industrialists, and the order of certain questions.

\section{Results}

\subsection{The Sample}

The present survey focused on the Mechanical Engineering Department in ENSEM, which comprises four domains: Quality Maintenance and Industrial Safety (Qualité Maintenance et Sécurité Industrielle - QMSI), Mechanical Systems Engineering (Génie des Systèmes Mécaniques - GSM), Mechanical Conception and Integrated Production (Conception Mécanique et Production Intégrée - CMPI), and Industrial Processes and Plastics (Procédés Industriels et Plasturgie - PIP). 210 industrialists were contacted, but only 51 of them returned the completed questionnaire. Each of them had one engineer who had recently graduated from ENSEM in their company. The majority of the industrialists were male with $90.2 \%$, while females represented only $9.8 \%$. Their educational level is depicted in Figure 1.

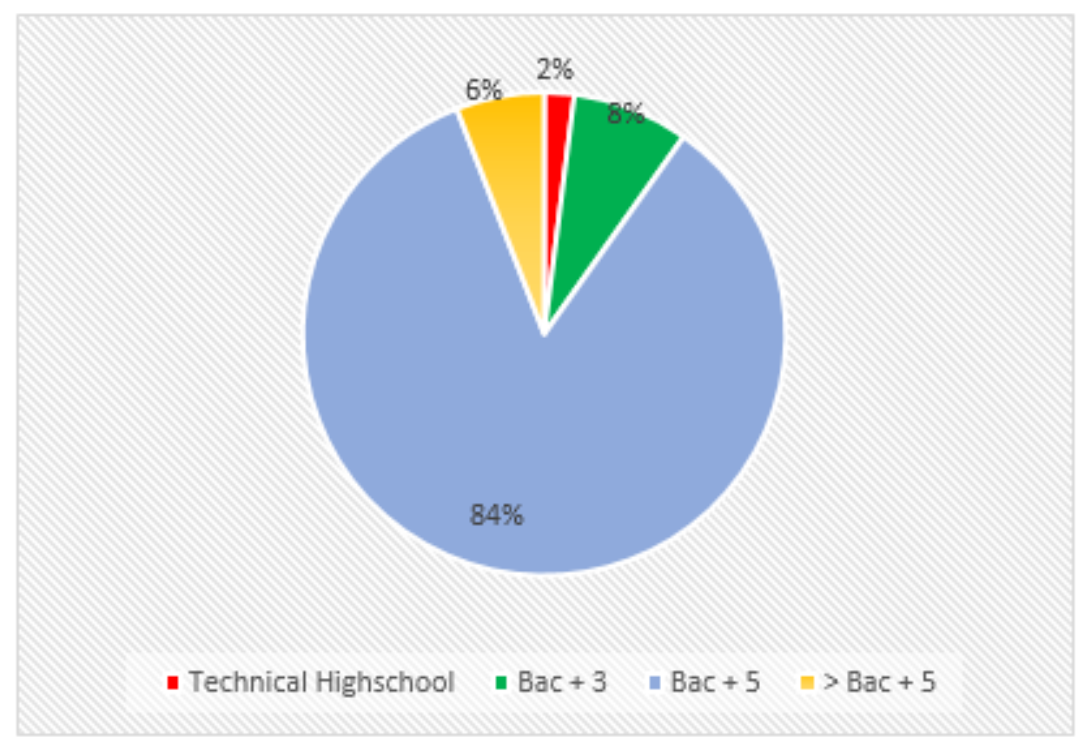

Figure 1. Respondent's level of training

It is noted that $84 \%$ had a Master's degree (High school degree +5 years in college) and were mostly engineers in different fields. The 51 industrialists were active in different sectors related to mechanical engineering, such as: the Engineering office, Mechanical and Industrial Engineering, the Automotive Industry, as presented in the following pie chart: 


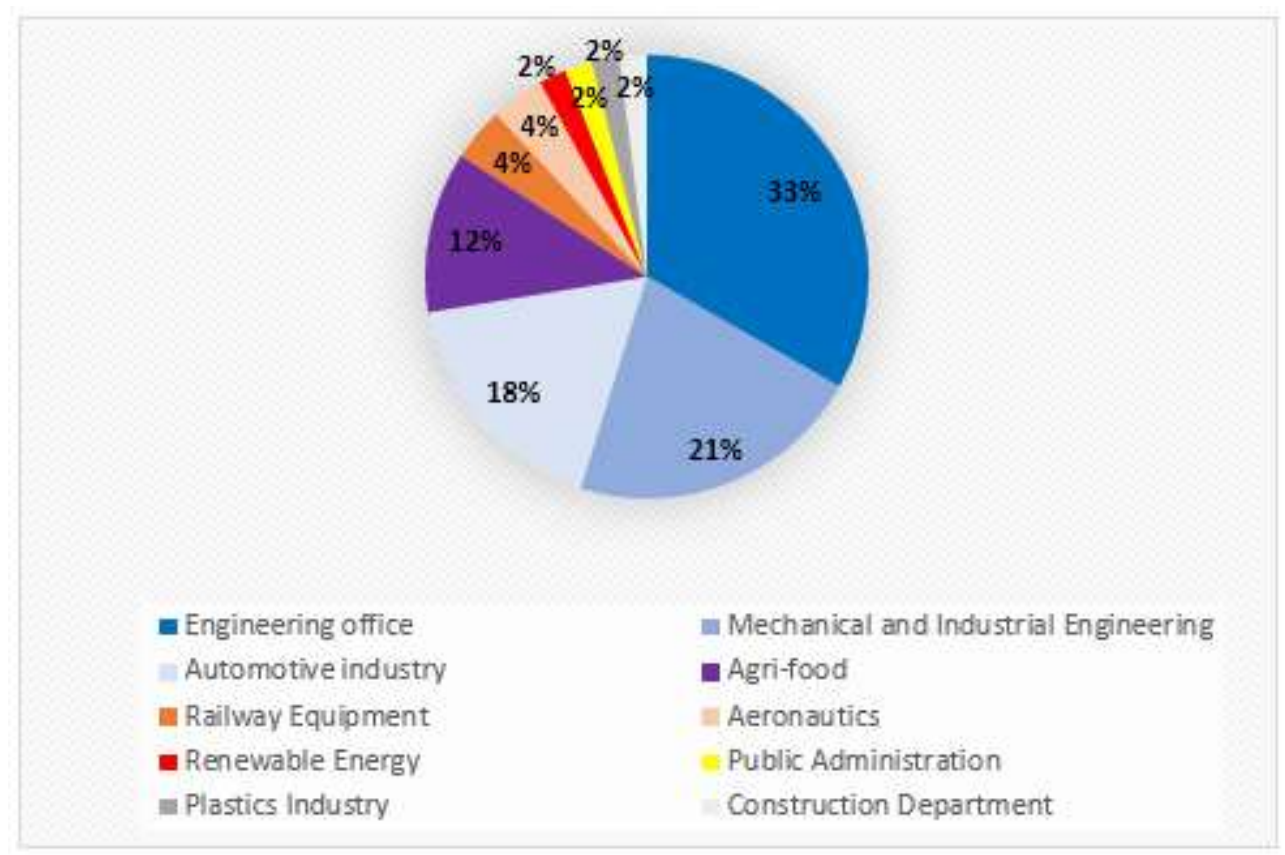

Figure 2. The different sectors of the companies surveyed

Figure 2 shows the distribution of mechanical engineers in percentage terms, in different Moroccan industrial sectors. $86.2 \%$ of these companies belonged to the private sector, $11.8 \%$ to the semi-public sector while the public sector represented only $2 \%$. Thus, ENSEM engineers were recruited mainly in the private sector.

These industrialists were invited to complete the questionnaire designed to assess engineering graduates from ENSEM classes ranging between 2013 and 2017. The selection of these classes was not arbitrary; it targeted recently trained individuals from the same training program. To guarantee the reliability of the data collected, the industrialists were asked to seal the questionnaires they completed. The engineers were aged between 22 and 28 years old and the majority of them were male (78.4\%), while females represented only $21.6 \%$. This is explained by the domination of men in the mechanical sector.

Figure 3 shows the fields where the engineers were active.

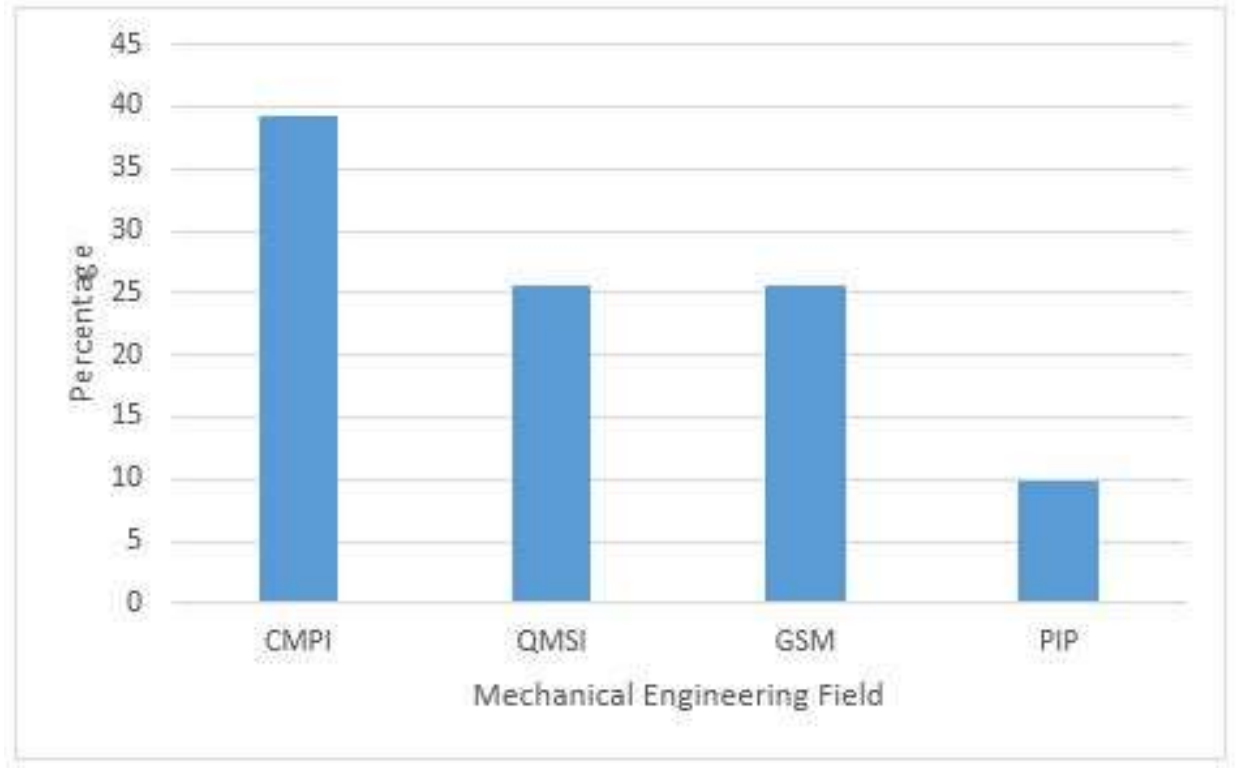

Figure 3. The surveyed engineering fields 
The participation rate from the PIP branch was low in comparison with the other branches. It is worth noting that PIP is a new specialty in ENSEM.

\subsection{Analysis of Results}

The results presented herewith pertain to the analysis of the data collected from 51 industry leaders. Each of these industrialists had one recently-graduated mechanical engineer working under them. Thus, each industrialist considered the recently-graduated engineer in their company to respond to the questionnaire questions.

The analysis of the data collected in this survey was carried out using SPSS (Statistical Package for the Social Sciences) which is a software package used in statistical analysis of all kinds of data and the most suitable for research purposes. Figures 4, 5, 6,7 and 8 show the importance level and the acquisition level of the various components constituting the five competencies of ENSEM engineers.

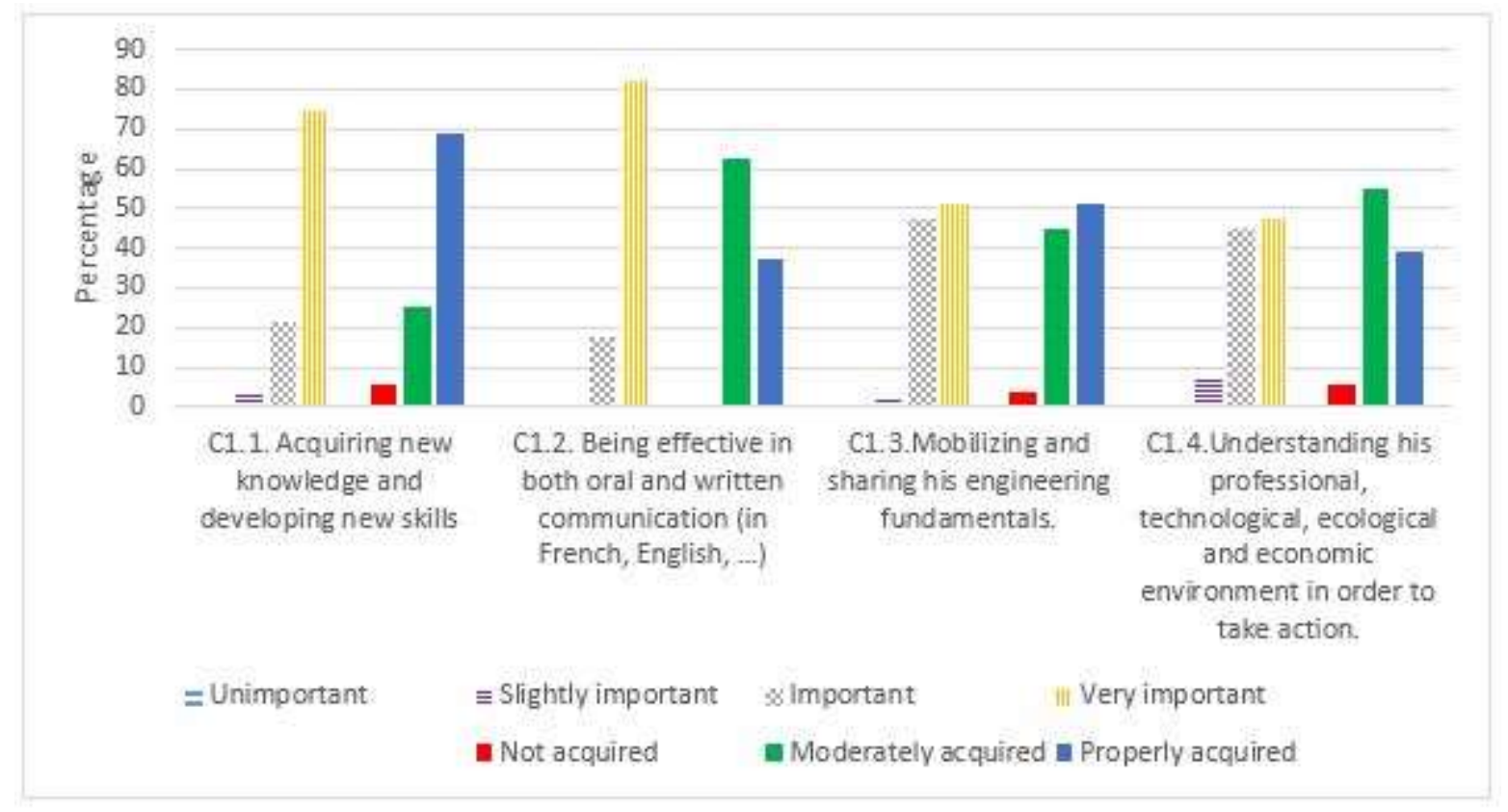

Figure 4. Importance Level and Acquisition Level of the different components of Competency1 in Percentage Terms 


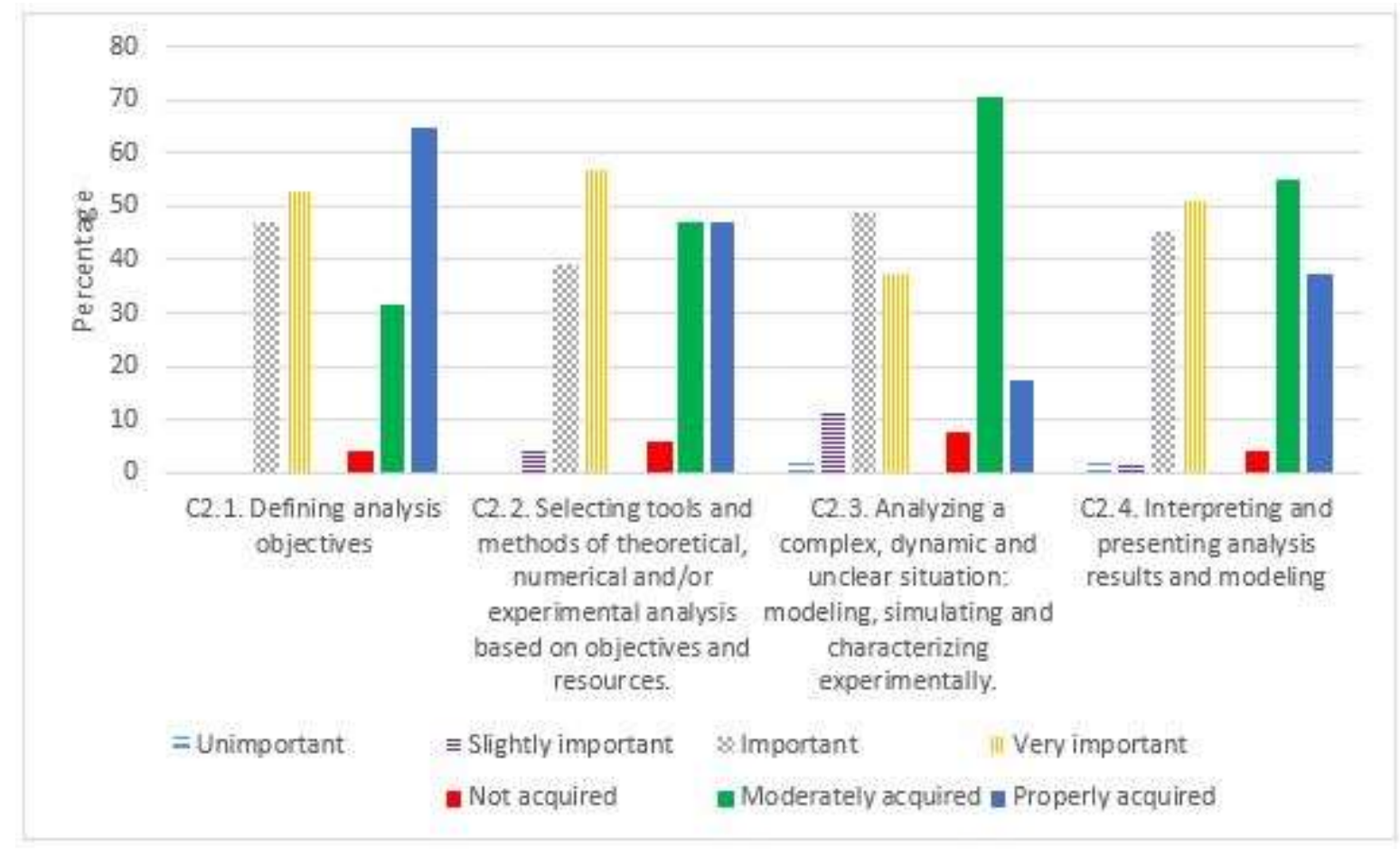

Figure 5. Importance Level and Acquisition Level of the different components of Competency2 in Percentage Terms

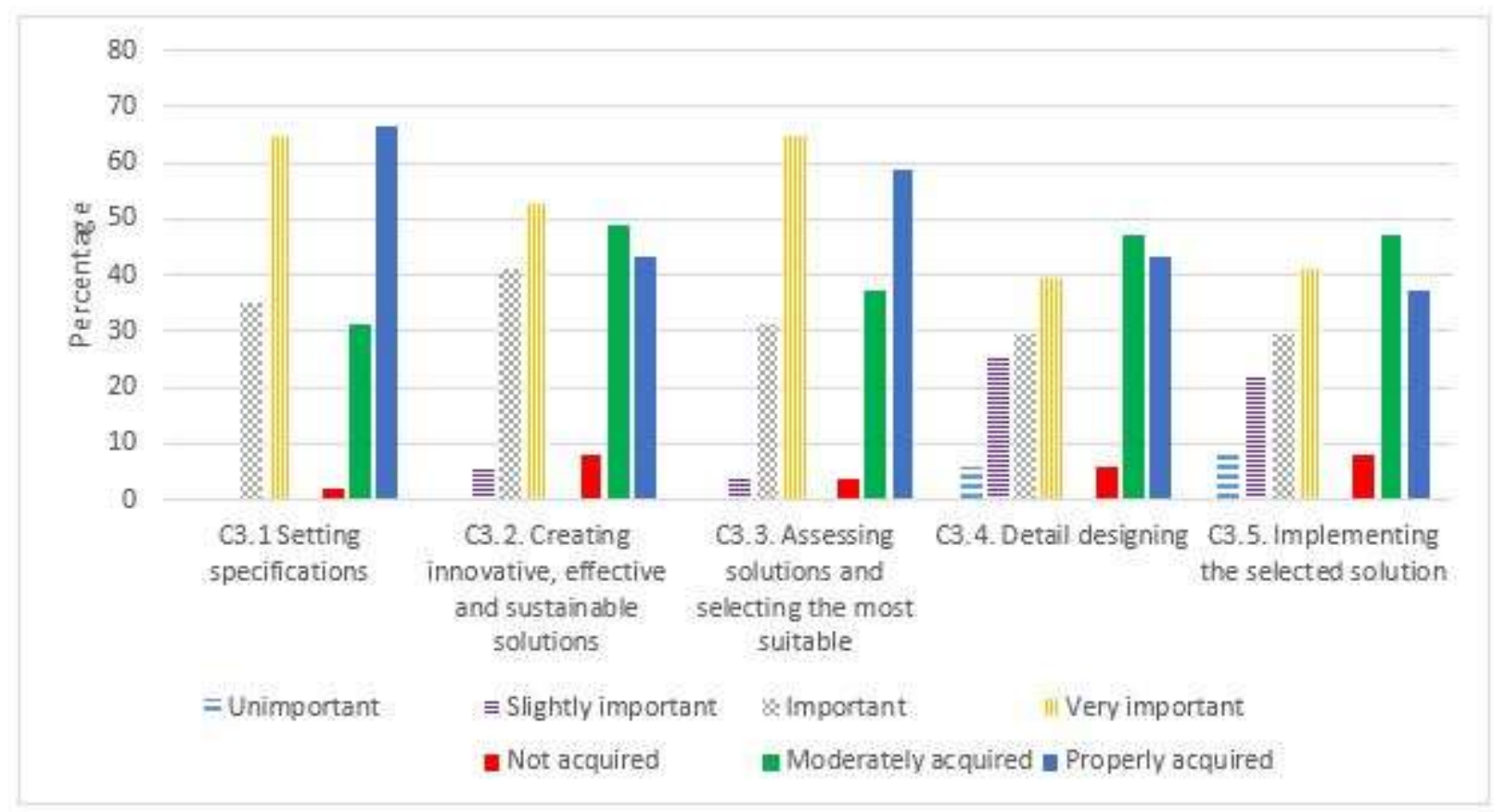

Figure 6. Importance Level and Acquisition Level of the different components of Competency3 in Percentage Terms 


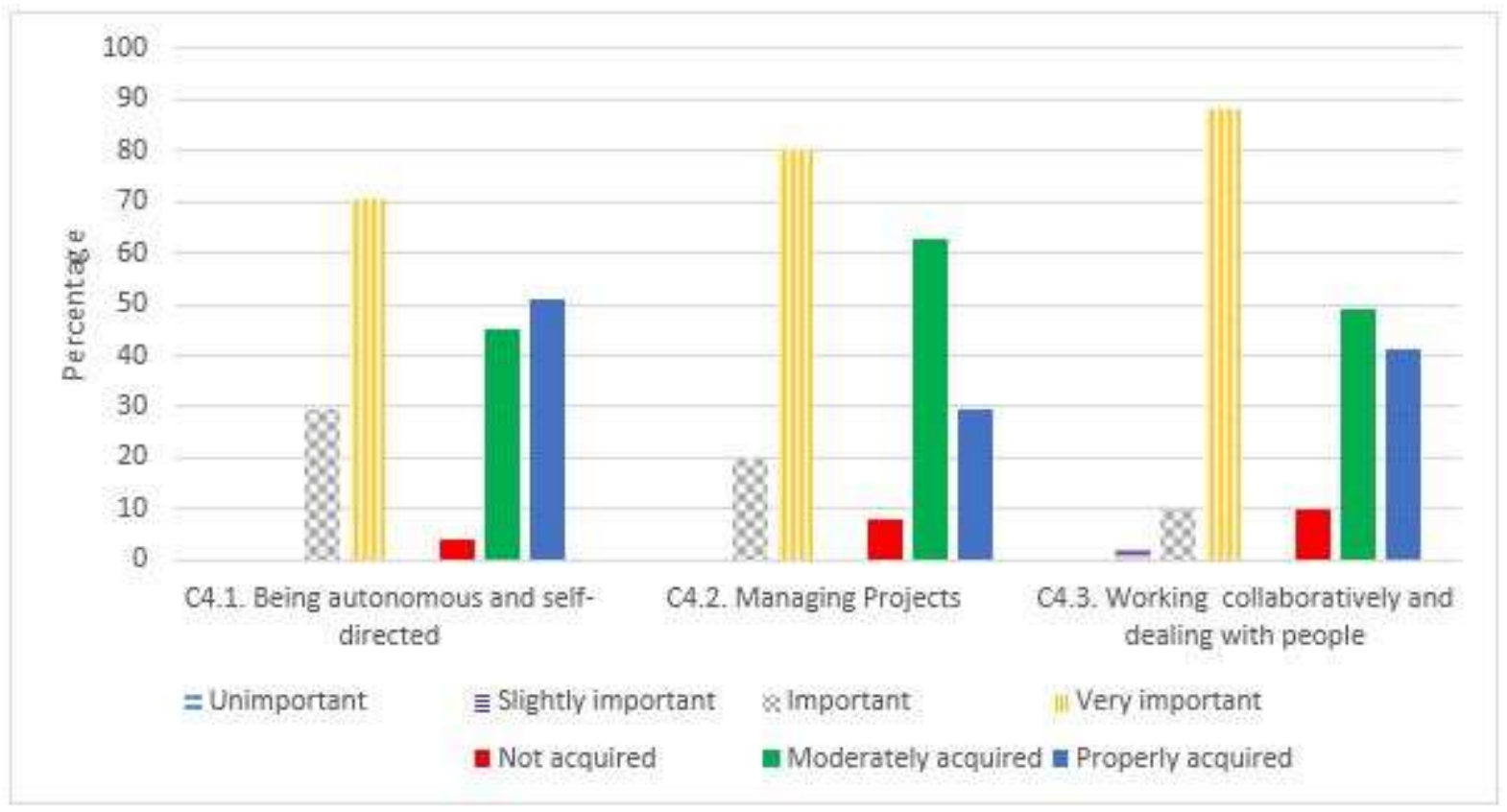

Figure 7. Importance Level and Acquisition Level of the different components of Competency4 in Percentage Terms

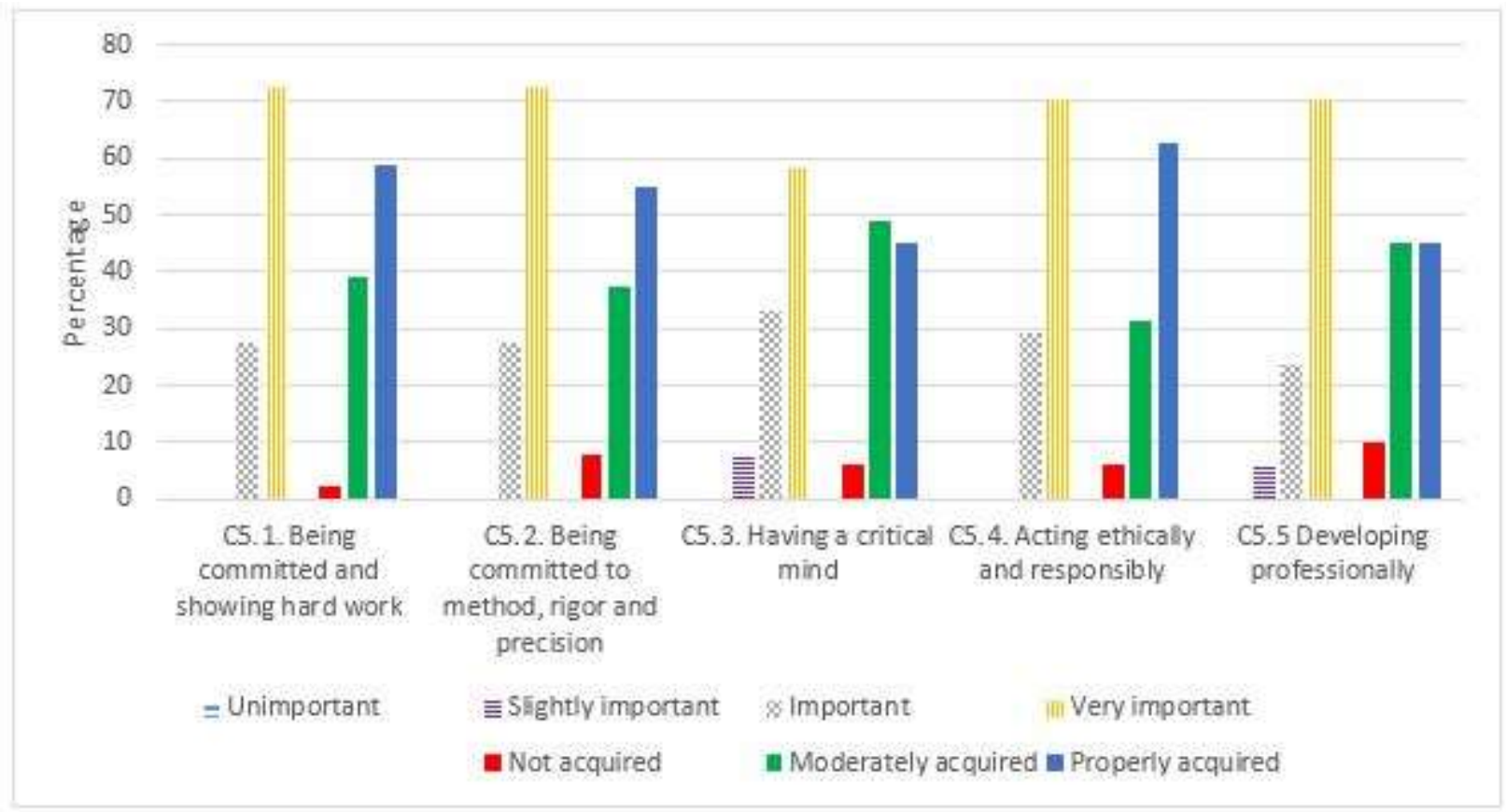

Figure 8. Importance Level and Acquisition Level of the different components of Competency5 in Percentage Terms

Figure 4 shows the importance level and the acquisition level of the various components constituting Competency 1 for ENSEM engineers. It should be noted that all the constituents of Competency 1 were of major importance to the company. Regarding the acquisition level, $62.7 \%$ had trouble understanding and handling two-way communication in French and English (C1.2). In addition, understanding the professional, technological, ecological and economic milieu remained a component requiring improvement. On the other hand, the ENSEM mechanical engineer was characterized by his capacity to acquire new knowledge, develop new skills and share the different facets of knowledge in the field of engineering. 
Figure 5 shows the results achieved after analyzing the data related to Competency 2. It was found that competency Components C2.1, C2.2 and C2.4 were of great importance and Component C2.3 was relatively important vis-à-vis the industrial market. As to the level of acquisition, 53\% of respondents were of the opinion that engineers have difficulty in selecting the correct tools and means of analysis suited to the desired objectives and resources. Furthermore, $78.4 \%$ of ENSEM engineers were unable to effectively analyze complex, dynamic and unclear situations, and 58.8\% had deficiencies at the level of interpreting and presenting analysis results and modeling. Nevertheless, defining the analysis objective (C2.1) was a component which had been properly acquired by $64,7 \%$ of ENSEM engineers.

Through the analysis of the response results pertaining to Competency 3 illustrated in Figure 6, it was established that all components of this competency were mostly very important. Besides, the components of innovation, efficiency and sustainability in designing and implementing solutions represented a weak point for the mechanical engineers of ENSEM. Moreover, being capable of designing a detail remained a competency to be enhanced for mastery. However, assessing the potential solutions to attain the most suitable was a component which had been properly acquired by $58.8 \%$ of the participants surveyed. Furthermore, the mechanical engineer of ENSEM demonstrated an ability to write project scope statements.

In regard to Competency 4, it was found that all components were very important. The project managing competency component (C4.2), which is one of the engineer's fundamentals, proved ill-assimilated for $70.5 \%$ of the people surveyed. The results also affirmed that the autonomy and self-direction traits had been properly acquired for $51 \%$ of the surveyed engineers.

Figure 8 describes the results of the responses regarding Competency 5. It was found that the five components of this competency were very important for companies. Concerning the level of acquisition, staff management, professional career, collaborative work and critical thinking (C5.3 and C5.5) required reinforcement in terms of training since they had been moderately acquired by more than half the participants surveyed. However, commitment, hard work, responsibility for one's actions and task fulfillment with rigor and precision (C5.1, C5.2 and C5.4) were abilities which had been highly mastered by the ENSEM Mechanical Engineers.

N.B: The Average Score, the Standard Deviation and the Variance for the importance level and the acquisition level for each component of the five competencies were calculated. It was found that all the values of the Standard Deviations were less than half the averages and therefore they were of low amplitude. Consequently, the values of the variance were very small. Furthermore, the responses of the participants in the survey were close to each other, which accounts for their homogeneity.

\subsection{Recapitulation}

To sum up the results related to each competency, the diagram presented in Figure 9 is revealing. It represents the various importance levels and then the diverse acquisition levels for the different competencies in percentage terms. 


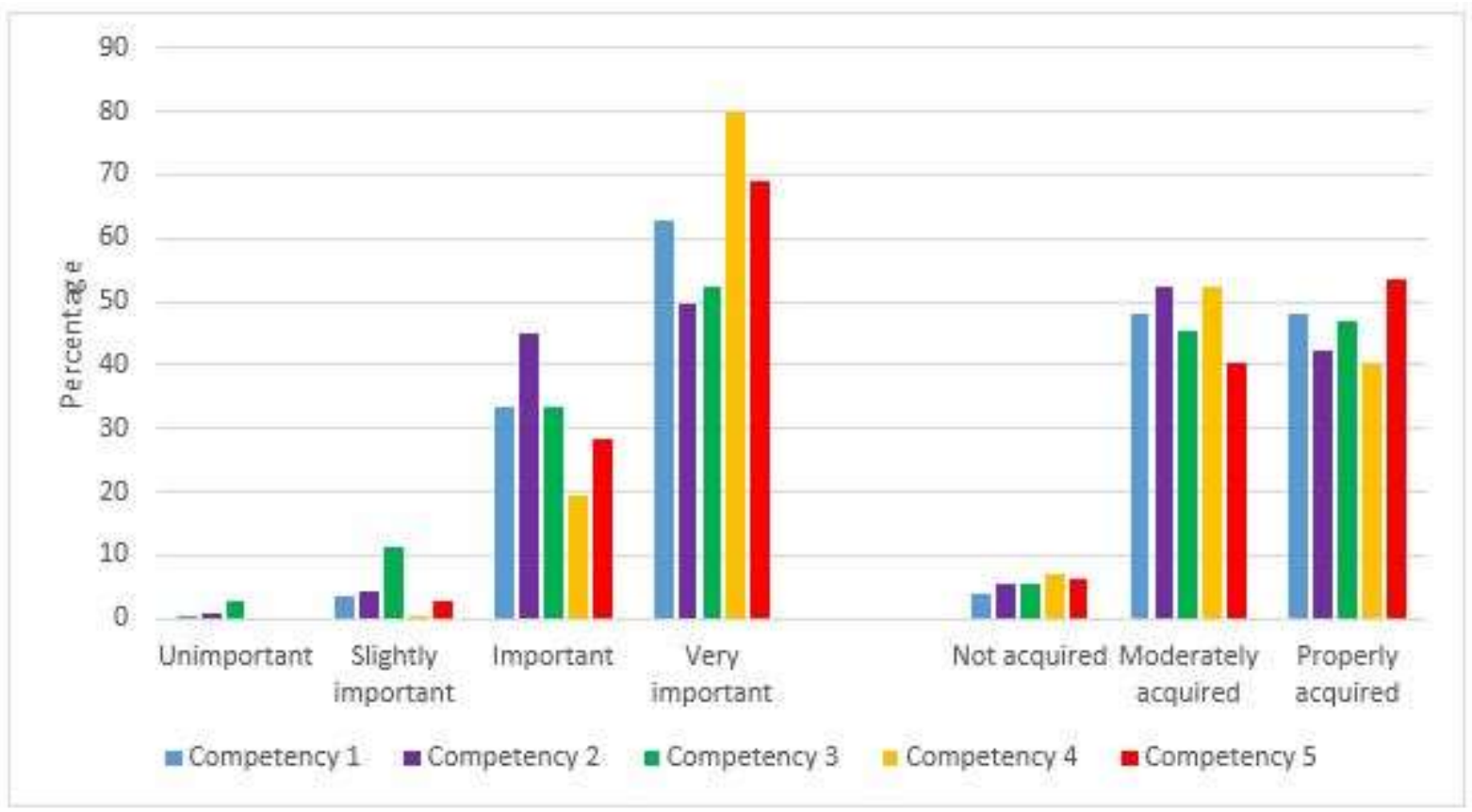

Figure 9. Importance Level and Acquisition Level for each competency in percentage

All competencies are proven to be crucial for a mechanical engineer. It can be observed that the sum of the percentages of the two modalities "moderately acquired" and "not acquired" exceeds 50\% for all competencies except Competency 5. Furthermore, it is remarkable that the acquisition level of Competencies 2 and 4 on one hand, and Competencies 1, 3 and 5 on the other, vary proportionally. Hence, the next step is to carry out an analysis of the correlations between the different components to study their interrelationships.

\subsection{Analysis of Correlations}

To infer the existence of a link between the components of each competency in terms of their level of acquisition by the laureate, it was deemed practical to use Pearson's Correlation Coefficient test with a 0.05 significance level. This process spotlights the results reflecting a close link between components, which means a correlation coefficient $r$ higher than 0.5, and a p-value of slope test lower than 0.05 (Cohen, 1988). Pearson's Correlation Coefficient allows the presence or absence of a linear relationship between two variables to be detected (Cohen, 1988).

Table 3 lists the results of this analysis corresponding to a significant correlation and a p-value equal to 0 . 
Table 3. Results of Pearson's Correlation Coefficient Test

\begin{tabular}{|c|c|c|}
\hline \multirow[b]{2}{*}{ Variables } & \multicolumn{2}{|c|}{ Level of acquisition } \\
\hline & $\begin{array}{l}\text { Correlated } \\
\text { Variables }\end{array}$ & $\begin{array}{l}\text { Correlation } \\
\text { coefficient }\end{array}$ \\
\hline \multirow[t]{2}{*}{$\begin{array}{l}\text { C1.3. Mobilizing } \\
\text { fundamentals. }\end{array}$} & - & - \\
\hline & C3.1 & 0.668 \\
\hline \multirow[t]{2}{*}{ C2.1. Defining analysis objectives } & $\mathrm{C} 4.2$ & 0.665 \\
\hline & C5.1 & 0.623 \\
\hline \multirow{2}{*}{$\begin{array}{l}\text { C2.2. Selecting tools and methods of theoretical, numerical } \\
\text { and/or experimental analysis based on objectives and } \\
\text { resources. }\end{array}$} & $\mathrm{C} 2.4$ & 0.631 \\
\hline & C5.5 & 0.662 \\
\hline $\begin{array}{l}\text { C2.3. Analyzing a complex, dynamic and unclear situation: } \\
\text { modeling, simulating and characterizing experimentally. }\end{array}$ & C5.3 & 0.642 \\
\hline \multirow[t]{2}{*}{$\begin{array}{l}\text { C2.4. Interpreting and presenting analysis results and } \\
\text { modeling }\end{array}$} & $\mathrm{C} 5.5$ & 0.622 \\
\hline & $\mathrm{C} 1.3$ & 0.635 \\
\hline \multirow{3}{*}{ C3.1. Writing Scope Statements } & $\mathrm{C} 4.2$ & 0.640 \\
\hline & C5.1 & 0.606 \\
\hline & C5.4 & 0.675 \\
\hline \multirow[t]{2}{*}{ C4.1. Being autonomous and self-directed } & C5.1 & 0.623 \\
\hline & C5.1 & 0.602 \\
\hline \multirow[t]{2}{*}{ C4.2. Managing Projects } & C5.4 & 0.830 \\
\hline & C5.5 & 0.650 \\
\hline \multirow{2}{*}{$\begin{array}{l}\text { C4.3. Working collaboratively and dealing with people } \\
\text { C5.1. Being committed and showing hard work }\end{array}$} & C5.5 & 0.608 \\
\hline & - & - \\
\hline \multirow{2}{*}{ C5.2. Being committed to method, rigor and precision } & C5.4 & 0.631 \\
\hline & C5.5 & 0.649 \\
\hline C5.3. Having a critical mind & - & - \\
\hline C5.4. Acting ethically and responsibly & C5.5 & 0.619 \\
\hline C5.5. Developing professionally & - & - \\
\hline
\end{tabular}

The results of Pearson's Correlation Test reveal that there is a linear linkage between, on one hand, being able to mobilize fundamental engineering knowledge, being a leader, being committed and showing hard work, acting ethically and responsibly and on the other hand, being able to write project scope statements. In fact, to write a scope statement, it is necessary to have a sense of listening to and analysis of customer requirements and offering the best proposals possible. In addition, the product suggested in the scope statement must comply with the various standards. The resolution of problems and dilemmas based on a decision-making process and the evaluation of choices according to standards are therefore essential for the drafting of relevant project scope statements.

This study also confirms the existence of a positive correlation between, on the one hand, the choice of analytical tools that are adequate for objectives and resources, and on the other, the interpretation of the results of analyses, modeling and professional development. This result is due to the attention the engineer must pay to the tools that can be utilized, in terms of precision and cost. The engineer is able to broaden his expertise in the multiple existing methods through the regular evaluation of needs and the continuous research of the means of development. Thus, the choice of methodology and the ability to analyze and synthesize the resulting data predominate over productivity and technology usage. Indeed, the former components allow for decision-making based on the purposes of analysis and modeling. 
Component C5.5, which concerns professional development, is correlated with several components, namely project and people management, collaborative work, interpretation and analysis of different results, action in a responsible manner... This result is conspicuous since this component, C5.5, touches on the continuous improvement of different skills acquired through self-evaluation to develop a critical mind on the one hand and the quest for career development on the other.

The managing projects component is correlated with being committed and showing hard work and acting ethically and responsibly. Indeed, the management of a project requires the development of different attitudes and the spirit of commitment and involvement of individuals.

\subsection{Confirmation or Rejection of Hypotheses}

In order to verify the initial hypotheses, the task is to calculate the average of the score averages for the components constituting each competency. The scores obtained permitted either the confirmation or the rejection of the initial hypotheses as shown in Table 4.

Table 4. Confirmation or rejection of the suggested hypotheses

\begin{tabular}{|c|c|c|c|c|}
\hline \multirow[t]{2}{*}{ Skills } & \multicolumn{2}{|c|}{ For the importance level } & \multicolumn{2}{|c|}{ For the acquisition level } \\
\hline & $\begin{array}{l}\text { Score } \\
\text { obtained }\end{array}$ & Result & $\begin{array}{l}\text { Score } \\
\text { obtained }\end{array}$ & Result \\
\hline $\begin{array}{l}\text { Competency 1. Understand, adapt } \\
\text { quickly, and communicate with } \\
\text { professional, technological, } \\
\text { ecological and economic } \\
\text { environment. }\end{array}$ & 4 & $\begin{array}{l}\text { The hypothesis } \mathrm{H} 1 \text { is } \\
\text { confirmed. } \\
\text { Competency } 1 \text { is very } \\
\text { important. }\end{array}$ & 2 & $\begin{array}{l}\text { The hypothesis } \\
\text { H1' is rejected. } \\
\text { Competency } 1 \text { is } \\
\text { moderately } \\
\text { acquired. }\end{array}$ \\
\hline $\begin{array}{l}\text { Competency 2. Starting from a } \\
\text { complex reality, identify, model } \\
\text { and analyze problems using a } \\
\text { scientific, holistic and } \\
\text { multidisciplinary approach. }\end{array}$ & 4 & $\begin{array}{l}\text { The hypothesis } \mathrm{H} 2 \text { is } \\
\text { confirmed. } \\
\text { Competency } 2 \text { is very } \\
\text { important. }\end{array}$ & 2 & $\begin{array}{l}\text { The hypothesis } \\
\text { H2' is rejected. } \\
\text { Competency } 2 \text { is } \\
\text { moderately } \\
\text { acquired. }\end{array}$ \\
\hline $\begin{array}{l}\text { Competency 3. Design and } \\
\text { implement innovative, effective } \\
\text { and sustainable solutions from a } \\
\text { business and/or research } \\
\text { perspective. }\end{array}$ & 4 & $\begin{array}{l}\text { The hypothesis } \mathrm{H} 3 \text { is } \\
\text { confirmed. } \\
\text { Competency } 3 \text { is very } \\
\text { important. }\end{array}$ & 2 & $\begin{array}{l}\text { The hypothesis } \\
\text { H3' is rejected. } \\
\text { Competency } 3 \text { is } \\
\text { moderately } \\
\text { acquired. }\end{array}$ \\
\hline $\begin{array}{l}\text { Competency } 4 \text {. Manage activities, } \\
\text { projects and people. }\end{array}$ & 4 & $\begin{array}{l}\text { The hypothesis } \mathrm{H} 4 \text { is } \\
\text { confirmed. } \\
\text { Competency } 4 \text { is very } \\
\text { important. }\end{array}$ & 2 & $\begin{array}{l}\text { The hypothesis } \\
\text { H4' is rejected. } \\
\text { Competency } 4 \text { is } \\
\text { moderately } \\
\text { acquired. }\end{array}$ \\
\hline $\begin{array}{l}\text { Competency } 5 . \text { Develop a } \\
\text { responsible professional profile } \\
\text { and act accordingly. }\end{array}$ & 4 & $\begin{array}{l}\text { The hypothesis H5 is } \\
\text { confirmed. } \\
\text { Competency } 5 \text { is very } \\
\text { important. }\end{array}$ & 3 & $\begin{array}{l}\text { The hypothesis } \\
\text { H5, is confirmed. } \\
\text { Competency } 5 \text { is } \\
\text { properly acquired. }\end{array}$ \\
\hline
\end{tabular}

It can be noticed that the five competencies are necessary for mechanical engineers in relation to Moroccan companies. At the same time, improvements should be made so that ENSEM mechanical engineers can achieve a proper acquisition of these competencies.

\section{Conclusion and Perspectives}

In this examination, the endeavor was to define and justify the selected methodology, which was founded on a quantitative study. This was a survey conducted with industrialists from different business fields who shared their viewpoints regarding the training in mechanical engineering in ENSEM. This paper justifies the choice of the research model on which the study was based, i.e., the competency framework of mechanical engineering in EPFL. This model allowed the questionnaire handed to industrialists to be modified after its pre-testing. The analysis of the 
collected data was carried out via the descriptive statistics and the linear correlation of the SPSS software. The outcomes obtained enabled this paper to highlight the strengths and the weaknesses that lay transversally at the level of technical competencies, and to identify the correlations between the various components.

After carrying out the analysis of the importance and the acquisition levels of the competencies required in the industrial milieu, it was possible to underline that all the designated competencies were deemed fundamental in the business profile of an engineer. In this respect, there is reason to believe that it is imperative to set forth some recommendations in order to address the various weaknesses in the components of competencies that are not acquired or moderately acquired. At the ENSEM, it is necessary to improve oral and written communication level by urging engineering students to prepare presentations about mechanical engineering concepts that could be delivered in seminars; to read and share the content of scientific and professional essays; ... etc. Seminars should also be organized revolving around analysis technologies and focusing training on specific tools to achieve the mastery level of theoretical, digital and empirical analysis methods. Furthermore, it is necessary to develop planning the accomplishment of projects requiring the ability to design, simulate and implement an innovative and effective set of solutions, and encouraging the drafting of synthesized analysis reports. There is also a need to focus on organizing reverse engineering workshops and visits to various industrial facilities and encouraging engineering students to partake in disparate projects and have varied duties, which would enable them to enrich their personal record of projects and improve their competencies.

The main challenge of this questionnaire in terms of the mechanism to be put in place for the collection of the desired data was to motivate specific and often busy professional leaders to answer nearly 34 questions. The solution adopted was to contact the laureate engineers of the ENSEM to obtain the contact details of their superiors and then to send them the questionnaire by email, or to travel and give it directly by hand. We followed this approach because it allowed us to personalize the questionnaire by indicating the name of the laureate we wished to evaluate and thereby maintaining traceability.

The limitations of the study lay in the limited number of the sample. To remedy this, it will be necessary to carry out a qualitative study in the form of semi-directive interviews with industrial managers and professors to enrich the results obtained.

The next step consists in checking the outcomes obtained by way of semi-structured interviews with industrialists. Later, it appears quintessential to incorporate other stakeholders, such as teachers and directors, so that they contribute to the investigation. This would subsequently lead to the suggestion of action plans to improve ENSEM mechanical engineering training programs by benefitting from various quality tools and testing their feasibility.

Such projects are strategic for the sustainable improvement of engineering science training quality, especially since the world is increasingly depending on technology.

\section{Acknowledgements}

The authors wish to thank the Moroccan industrialists and laureates of Mechanical Engineering of ENSEM for their participation in the survey.

\section{Disclosure statement}

No potential conflict of interest was reported by the authors.

\section{References}

Ait haddouchane, Z., Faraj, K., Bakkali, S., \& Ajana, S. (2016). Etude critique des référentiels de compétences du génie mécanique. The journal of quality in education, 7, 48-59.

Ait haddouchane, Z., Bakkali, S., Ajana, S., \& Gassemi, K. (2017). The application of the competency-based approach to assess the training and employment adequacy problem. International Journal of Education, 1, 1-18.

Basque, J., \& Rogozan, D. (2013, June). Vers une méthode d'ingénierie de l'approche-programme en enseignement supérieur. Paper presented at the annual meeting Questions de pédagogies dans l'enseignement supérieur (QPES). Les innovations pédagogiques en enseignements supérieur: Pédagogies actives en présentiel et à distance, Sherbrooke, Canada.

Champy-Remoussenard, P. (2015). Les transformations des relations entre travail, éducation et formation dans l'organisation sociale contemporaine: questions posées par trois dispositifs analyseurs. Revue française de pédagogie, 190, 15-28. https://doi.org/10.4000/rfp.4675

Charles, N. (2014). Quand la formation ne suffit pas : la préparation des étudiants à l'emploi en Angleterre, en 
France et en Suède. Sociologie du travail, 56, 320-341.

Chauvigné, C., \& Coulet, J. C. (2010). L'approche par compétences : un nouveau paradigme pour la pédagogie universitaire?. Revue française de pédagogie, 172, 15-28. https://doi.org/10.4000/rfp.2169

Cros, F., \& Raisky, C. (2010). Référentiel. Recherche et formation, 64, 105-116.

Deschryver, N., Charlier, B., \& Fürbringer, J. M. (2011). L'approche par compétences en pratique. Education \& Formation, e-296, 57-68.

Felouzis, G. (2008). Des mondes incertains : les universités, les diplômés et l'emploi. Formation emploi, 101, 135-147.

Filippi, C., Cantaroglou, F., Gerbé, O., \& Raynauld, J. (2012, May). Du portefeuille de formation au portfolio de compétences : valoriser les communautés professionnelles pour favoriser l'accès à l'emploi. Paper presented at the annual meeting ACFAS, Montréal, Canada.

Gardelle, L., Cardona Gil, E., Benguerna, M., Bolat, A., \& Naran, B. (2017). The spread of European models of engineering education: the challenges faced in emerging countries. European Journal of Engineering Education, 42(2), 203-218. https://doi.org/10.1080/03043797.2016.1241983

Ghouati, A. (2010). The Bologna Process in the Maghreb. AIU Horizons, Association Internationale des Universités, $16,20-22$.

Grenier, C., \& Pauget, B. (2007). Qu'est-ce que la recherche en management ?. Recherche en soins infirmiers, 91(4), 12-23. https://doi.org/10.3917/rsi.091.0012

J. Cohen. (1988). Statistical power analysis for the behavioral sciences. New York, USA: EA 2nd ed.

J. W. Creswell. (2013). Research Design: Qualitative, quantitative, and mixed methods approaches, 4th edition. USA: Sage.

Mérenne-Schoumaker, B. (2006). Développer une approche par compétences dans la formation universitaire. Bilan de trois expériences en géographie urbaine et économique. Bulletin de la Société géographique de Liège, 48, 7-17.

Postiaux, N., \& Robert, F. (2013, June). Référentiel de compétences et learning outcomes à l'Ecole Polytechnique de Bruxelles. Paper presented at the annual meeting Questions de pédagogie dans l'enseignement supérieur, Sherbrooke, Canada.

Roegiers, X. (2016). Un cadre conceptuel pour l'évaluation des compétences: International Bureau of Education of UNESCO. Retrieved from http://unesdoc.unesco.org/images/0024/002451/245195f.pdf

Royaume du Maroc, Ministère de l'Industrie, de l'Investissement, du Commerce et de l'Economie Numérique. (2014). Plan d'accélération industrielle $2014 \quad-\quad 2020 . \quad$ Retrieved from http://www.mcinet.gov.ma/fr/content/plan-d\%E2\%80\%99acc\%C3\%A91\%C3\%A9ration-industrielle-2014-2020 $-0$

Terfous, N. (2006). Mondialisation et marché du travail dans les pays développés. Economie \& prévision, 172, 117-124. https://doi.org/10.3406/ecop.2006.7484

Vincens, J. (2005). L'adéquation formation-emploi. In Giret, J. F. (Eds.), Des formations pour quels emplois? (p.149-162). Paris, France: La Découverte.

X. Roegiers. (2010). Des curricula pour la formation professionnelle initiale. Bruxelles, Belgique: DeBoeck. 